\title{
Construction Damages a Prehistoric Caddo Indian Archaeological Site at the City of Gilmer's proposed Lake Gilmer, Upshur County, Texas
}

Timothy K. Perttula

Heritage Research Center, Stephen F. Austin State University

Bo Nelson

Heritage Research Center, Stephen F. Austin State University

Follow this and additional works at: https://scholarworks.sfasu.edu/ita

Part of the American Material Culture Commons, Archaeological Anthropology Commons, Environmental Studies Commons, Other American Studies Commons, Other Arts and Humanities Commons, Other History of Art, Architecture, and Archaeology Commons, and the United States History Commons

Tell us how this article helped you.

This Article is brought to you for free and open access by the Center for Regional Heritage Research at SFA ScholarWorks. It has been accepted for inclusion in Index of Texas Archaeology: Open Access Gray Literature from the Lone Star State by an authorized editor of SFA ScholarWorks. For more information, please contact cdsscholarworks@sfasu.edu. 
Construction Damages a Prehistoric Caddo Indian Archaeological Site at the City of Gilmer's proposed Lake Gilmer, Upshur County, Texas

\section{Creative Commons License}

(c) (1) (8)

This work is licensed under a Creative Commons Attribution-NonCommercial 4.0 International License 


\title{
Construction Damages a Prehistoric Caddo Indian Archaeological Site at the City of Gilmer's proposed Lake Gilmer, Upshur County, Texas
}

\author{
Timothy K. Perttula and Bo Nelson
}

\section{INTRODUCTION}

In March 1996, the archaeological work being conducted at the proposed Lake Gilmer was called to a halt by the archaeological contractor (Horizon Environmental Services of Austin, Texas) and the City of Gilmer long before the required archaeological mitigation of important prehistoric Caddo sites had been completed. The reasons are still somewhat obscure (cf. Black 1997).

After a delay of more than 1.5 years in the completion of the archaeological investigations at the proposed Lake Gilmer, a federal and state-permitted reservoir in Northeast Texas, the Division of Antiquities Protection at the Texas Historical Commission has taken up the task of completing the archaeological work, following the legal dictates laid down by State Representative Bob Glaze during the last legislative session (see discussion by Black 1997 and Martin 1997). This work will apparently concentrate on completing the investigations of 4IUR133, a large Middle (ca. A.D. 1200-1400) and Late Caddoan (ca. A.D. 14001680) period habitation site.

While the work at 4IUR133 is long over-due, we believe that additional archaeological investigations are warranted at Lake Gilmer: (1) evaluation of the research significance of a recently discovered Caddo Indian site within the Lake Gilmer floodpool that has been damaged by reservoir construction-related activities, and (2) evaluation of the research significance of the more than 30 archacological sites discovered within the reservoir floodpool since 1996 by the Northeast Texas Archaeological Society. All of these sites must be considered by state law to be State Archeological Landmarks since they are on land owned by the City of Gilmer (a political subdivision), and they warrant further consideration.

In this paper, we discuss site 41 UR210 (the 852 Bridge site), a previously unreported and newly discovered prehistoric Caddo Indian site that has been damaged by construction activities associated with the proposed Lake Gilmer project in Upshur County, Texas. The site is on a small alluvial terrace adjacent to Kelsey Creek, on property owned by the City of Gilmer, and it was not recorded during the archeological survey completed for the project several years ago. Kelsey Creek is a tributary of Little Cypress Creek.

This prehistoric Caddo Indian site has been damaged by construction-related activities associated with the construction of a new and higher bridge on FM 852 that will cross over the proposed Lake Gilmer. The site has been damaged by blading and bulldozing activities to obtain sand, and sediments have been removed to an unknown depth over an area more than 2 acres in size (Figure 1). Considerable amounts of prehistoric Caddoan vessel and pipe ceramic sherds have been exposed in this damaged area, and it is considered likely that prehistoric habitation features (middens and structural features)--as well as Caddo burial features--are present at the site, and may have already been damaged. 


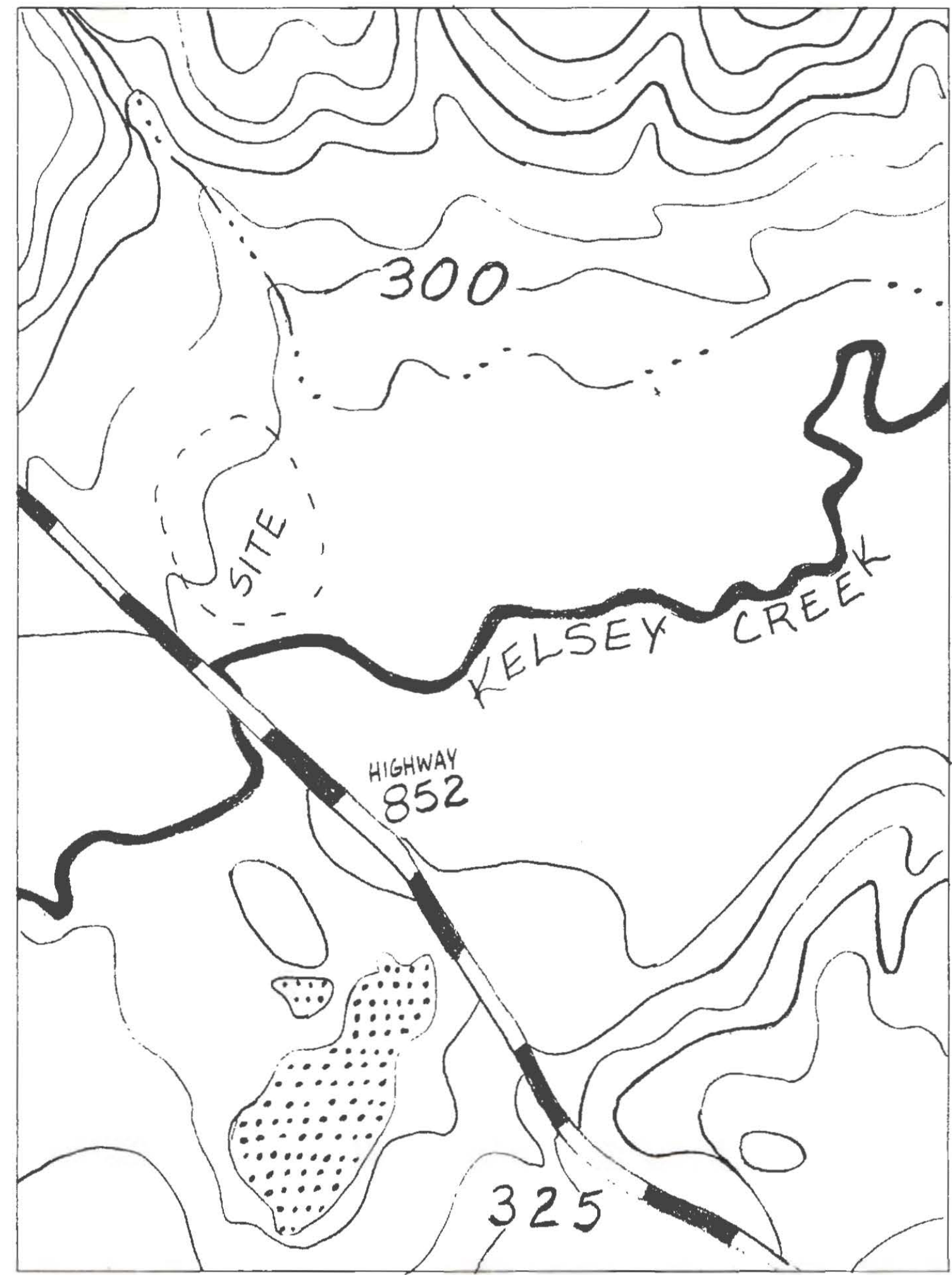

Figure 1. Site Map for the 852 Bridge Site (41UR210) 


\section{WHAT WE KNOW ABOUT THE 852 BRIDGE SITE (41UR210)}

The 852 Bridge site was reported by the junior author in February 1997, after he noted that sediments were being removed from an area along Kelsey Creek where archaeological sites had not been previously located during the Horizon survey. An area approximately $100 \mathrm{x}$ 100 meters in size ( 2.5 acres) had been disturbed. We reported the archaeological discovery to the Texas Historical Commission on February 23, 1997, and a month or so later, the site was examined by an archaeologist with the Texas Department of Transportation (TxDOT), since it was believed then that TxDOT had legal responsibilities for the site because it was damaged as a result of activities associated with highway construction. The site was relocated, although the results of these investigations have not been reported to date. It was determined that the damage to the site was caused by the removal of sand for the bridge embankment. At that time, another previously unrecorded Caddoan archaeological site (41UR211) was found by the TxDOT archaeologist within the FM 852 Bridge right-ofway; this site had been almost completely obliterated by construction activities.

On at least two occasions after the TxDOT effort, representatives of the Texas Historical Commission visited the 852 Bridge site. Again, the results of these visits have not been reported to date.

The 852 Bridge site appears to be a single component Caddo archaeological site occupied between about A.D. 1400-1450. Based on the apparent size of the site, and the composition of the artifact assemblage, the 852 Bridge site is probably a small and permanently occupied hamlet of Caddo horticulturists who farmed the sandy soils of the Kelsey Creek valley, and hunted across the Little Cypress Creek basin. These sorts of Caddo sites commonly have preserved features from wood structures, hearth and pit features, trash midden deposits, and family cemeteries, and there is every reason to expect these archaeological remains at the 852 Bridge site.

Included in the archaeological materials known to come from the site are 278 ceramic sherds, one ceramic pipe stem, 28 pieces of lithic debris, one flake tool, and a single piece of animal bone. These materials were exposed on the surface of the site after the highwayrelated construction disturbances.

Among the 278 Caddo ceramic sherds are 198 plain body sherds, four plain base sherds, and 76 decorated rim and body sherds (Figure 2). Of those sherds with an apparent temper, most have been tempered with grog or crushed sherds (58 percent), a combination of grog and burned bone ( 25 percent), or simply with crushed and burned bone (17 percent). Some 54 of the sherds have a fine sandy paste without any apparent temper inclusions.

The decorated sherds are mainly from Pease Brushed-Incised jars with brushed rims and brushed-incised bodies ( $\mathrm{n}=46$ sherds, including two rims). Among the 20 incised sherds are three cross-hatched incised rims, probably from Maydelle Incised and/or Canton Incised cooking jars, and the seven punctated sherds are likely to be from the same sort of vessels. The two small engraved sherds have single lines, limiting the identification of the ceramic type, and there is also one appliqued sherd (probably from a Pease BrushedIncised vessel) (see Figure 2). 


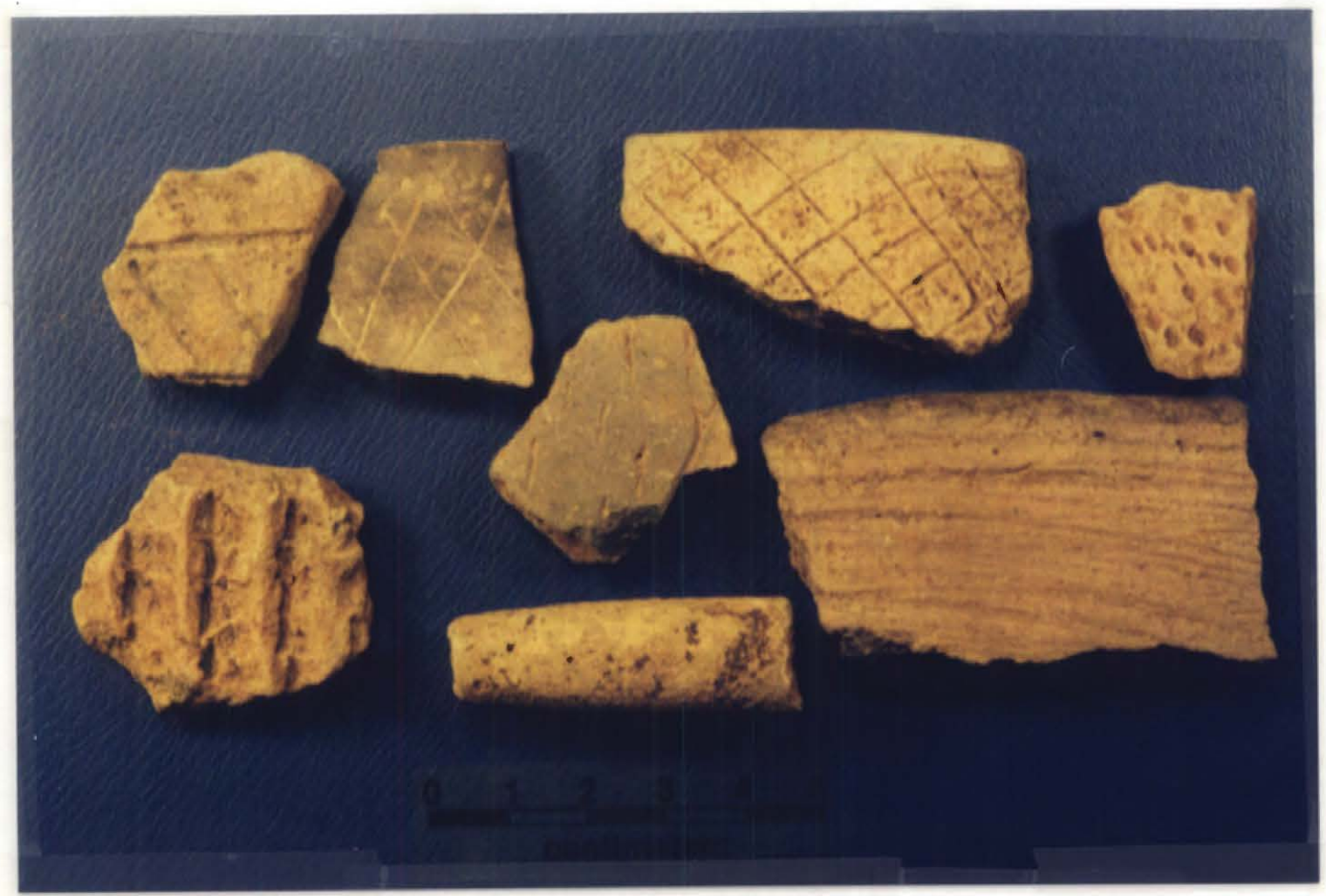

Figure 2. Decorated Ceramics and Pipe Sherd from the 852 Bridge Site (41UR210) 
The high frequency of brushed pottery sherds, and the occurrence of Pease BrushedIncised and Maydelle Incised ceramic types, indicates that the 852 Bridge site was likely occupied during the Whelan phase (Thurmond 1990). Most of the known Whelan phases in the Cypress Creek basin are present "in the middle reaches of Big Cypress Creek" (Thurmond 1990:228), and few if any components of the Whelan phase have been identified and/or investigated in the Little Cypress Creek basin. The 852 Bridge site thus may have the potential to contribute important anchaeological information on Caddo lifeways during this little known period.

The broken ceramic pipe stem (about $41 \mathrm{~mm}$ in length) appears to be from a long-stemmed clay pipe (see Figure 2). This was the popular style of smoking pipe for Caddo groups between about A.D. 800-1450, after which small elbow-shaped pipes were preferred.

The flake tool is a retouched flake of a white chert, believed to have obtained in Red River gravels. This kind of unifacial tool was probably used by Caddo women and men for cutting and scraping of animal bones and hides obtained during hunting. The lithic debris is fairly evenly represented by the use of local (61 percent) and non-local (39 percent) raw materials. The local raw materials include quartzite $(n=15)$ and petrified wood $(n=2)$ that could have been obtained by prehistoric Caddo groups from upland gravel sources. The non-local raw materials include flakes of novaculite, chalcedony, and high-quality cherts from Red River gravel sources. These materials were probably obtained in trade with related Caddo groups who lived along the Red River in what is now Northeast Texas.

\section{RECOMMENDATIONS}

To prevent further damage to this prehistoric Caddo site, and to formally assess its National Register of Historic Places eligibility and State Archeological Landmark designation status before the site is inundated, the Texas Historical Commission and the City of Gilmer should take decisive actions to halt the damaging construction activities being conducted for the project in the immediate vicinity of the site. We also recommend that these offices immediately initiate consultation under the project's Memorandum of Agreement with all responsible and concerned parties, such as the City of Gilmer, the construction contractor, the Fort Worth District of the Corps of Engineers, the Caddo Indian Tribe of Oklahoma, and interested persons under the Section 106 process, to determine appropriate evaluation and mitigation measures for this newly discovered and apparently important prehistoric archeological site. These measures should be completed before the site is inundated this winter by Lake Gilmer, and before further sediments are removed from the site for construction-related purposes.

\section{REFERENCES CITED}

Black, Steve

1997 Archeology at Lake Gilmer: Bad Precedents and Conflicting Interests. Council of Texas Archeologists Newsletter 21(2):7-9.

Martin, W. A.

1997 Bad Precedents, Abominations, and Apathy: The Gilmer Incident and CTA. Council of Texas Archeologists Newsletter 21(2):10-11. 
Thurmond, J. Peter

1990 Archeology of the Cypress Creek Drainage Basin, Northeastern Texas and Northwestern Louisiana. Studies in Archeology 5. Texas Archeological Research Laboratory, The University of Texas at Austin. 